\title{
Inter-annual variability in diet of non-breeding pelagic seabirds Puffinus spp. at migratory staging areas: evidence from stable isotopes and fatty acids
}

\author{
R. A. Ronconi ${ }^{1,2, *}$, H. N. Koopman ${ }^{2,3}$, C. A. E. McKinstry ${ }^{2,3}$, S. N. P. Wong ${ }^{1,2}$, \\ A. J. Westgate ${ }^{2,3}$ \\ ${ }^{1}$ Department of Biology, Dalhousie University, 1355 Oxford Street, Halifax, Nova Scotia B3H 4J1, Canada \\ ${ }^{2}$ Grand Manan Whale and Seabird Research Station, 24 Route 776, Grand Manan, New Brunswick E5G 1A1, Canada \\ ${ }^{3}$ Department of Biology and Marine Biology, University of North Carolina Wilmington, 601 South College Road, Wilmington, \\ North Carolina 28403, USA
}

\begin{abstract}
During nesting periods, seabirds are known to exhibit considerable inter-annual variability in diets, yet little is known about the diets of pelagic seabirds during non-breeding periods. Over 5 yr (2005 to 2009), we studied dietary partitioning between sympatric greater and sooty shearwaters, Puffinus gravis and P. griseus, during migratory staging periods in the Northwest Atlantic. Stable-isotope ( $\left.\mathrm{SI}_{i} \mathrm{n}=253\right)$ and fatty-acid $\left(\mathrm{FA}_{;} \mathrm{n}=127\right)$ signatures from blood samples were used to assess inter-annual patterns in diet and quantify prey choices. In addition to significant effects of year, capture site, and body condition, SI signatures revealed subtle, but consistent, dietary partitioning between species. In all years, greater shearwaters fed at slightly higher trophic levels (overall mean $\left.\delta^{15} \mathrm{~N}=13.6 \%\right)$ and lower $\delta^{13} \mathrm{C}(-19.1 \%)$ than sooty shearwaters $\left(\delta^{15} \mathrm{~N}=13.3 \%, \delta^{13} \mathrm{C}=-18.9 \%\right)$. SI mixing models revealed that sooty shearwaters relied more heavily on euphausiids Meganyctiphanes norvegica, while greater shearwaters consumed more herring Clupea harengus, squid Illex illecebrosus, and, in some years, mackerel Scomber scombrus. In 2005/2006, bird diets consisted primarily of herring and krill, but demonstrated a shift towards krill and squid during 2007-2009. FA from bird plasma showed little inter-specific partitioning but a strong signal of annual variation for both species. We used a subset of prey FA and a modified multivariate approach to model bird diets and obtained dietary preferences broadly in agreement with SI results. The present study revealed inter-annual variability and dietary partitioning in sympatric species of pelagic seabirds, and highlights potential shifts in prey availability to predators in the Bay of Fundy.
\end{abstract}

KEY WORDS: Foraging ecology $\cdot$ Shearwaters $\cdot$ Stable isotopes $\cdot$ Fatty acids $\cdot$ Bay of Fundy

\section{INTRODUCTION}

Seabirds are known to exhibit considerable interannual variability in their diets (Abraham \& Sydeman 2004, Tierney et al. 2008), particularly in response to changing food webs and oceanographic conditions (e.g. Montevecchi 2007). As a result, quantification of the diets of breeding seabirds is increasingly being used as an indicator of the health of fish stocks and marine ecosystems (Cairns 1987, Piatt et al. 2007, Einoder 2009). To date, however, very little is known about inter-annual variability in seabird diets outside of the breeding season. Breeding seabirds are central-place foragers, restricted to foraging locations and prey items within a limited range of nest sites. Thus, non-breeding seabirds, free of breeding constraints, may exhibit greater flexibility in their foraging tactics and prey choices. Sampling the diet of seabirds outside of the breeding season may provide insights into their true dietary breadth, and offer new opportunities for monitoring changes in marine ecosystems. 
Traditionally, non-breeding seabirds have been collected for dietary studies by lethal sampling (e.g. Brown et al. 1981). In recent decades, at-sea capture techniques have improved (Whitworth et al. 1997, Ronconi et al. 2010a), offering tremendous potential for non-lethal sampling of seabird diets using stableisotope (SI) and fatty-acid (FA) analysis techniques (Connan et al. 2005, Wang et al. 2007, Cherel et al. 2008, Tierney et al. 2008, Williams et al. 2008, Williams $\&$ Buck 2010). Here we examine the inter-annual variability in the diets of 2 species of sympatric seabirds, greater and sooty shearwaters Puffinus gravis and $P$. griseus, at a migratory staging area (winter feeding ground). To our knowledge, this is only the second study (see Suryan \& Fischer 2010) to use non-lethal methods to examine inter-specific and inter-annual variability in diets of pelagic seabirds outside of the breeding season.

Greater and sooty shearwaters are transequatorial migrants that utilize the entire North and South Atlantic and are among the top 20 seabird prey consumers globally (Brooke 2004), making them ideal indicator species for large-scale ocean ecosystems. These 2 species of shearwater have relatively segregated breeding grounds in the South Atlantic (Shirihai 2002), but highly sympatric non-breeding distributions in the North Atlantic (Brown 1986). In the western North Atlantic, both species are known to feed together in mixed flocks on a wide range of prey items, including fish, squid, euphausiids, and fisheries discards (Rees 1961, Brown et al. 1981, Moser \& Lee 1992). Previous studies of shearwater diets in this region have relied solely on stomach-content analyses (e.g. Brown et al. 1981).

Biochemical methods, including SI ratios and FA signatures, are widely used to study marine food webs (Hobson et al. 1994, Dahl et al. 2003, Dalsgaard et al. 2003, Iverson et al. 2007), and circumvent some of the biases associated with stomach-content analysis (Tierney et al. 2008). SI and FA signatures of animal tissues can provide a weighted and integrated average of diet over different time scales, depending on the types of tissue sampled. Turnover rates of avian blood suggest that integrated dietary information may be inferred over periods of weeks from SI (Hobson \& Clark 1992) and $\sim 5$ d from FA in plasma (A. Käkelä et al. 2007). Using a combination of SI and FA analysis therefore provides broader insight into seabird diets (Dahl et al. 2003, A. Käkelä et al. 2007, Tierney et al. 2008, Williams et al. 2008) at multiple temporal scales. Moreover, recent work has shown convergence between diet estimates derived from FA and SI (Tucker et al. 2008).

Although analytical techniques and dietary mixing models have been developed for SI analysis of animal tissues (Phillips \& Gregg 2003, Moore \& Semmens 2008), uncertainty remains over the use of plasma FA for estimating avian diets (R. Käkelä et al. 2005, 2009, A. Käkelä et al. 2007, Tierney et al. 2008) because the extent to which dietary FA are modified is greater in birds than in mammals (Klasing 1998, Williams \& Buck 2010). In mammals, dietary FA are packaged directly into lipoprotein molecules called chylomicrons that travel in the blood; consequently chylomicrons contain high concentrations of recently consumed FA and can be used by researchers to infer diet (e.g. Cooper et al. 2005). Birds instead package FA into portomicrons (Stevens 1996, Klasing 1998), which are modified by the liver prior to entry into general circulation and consequently contain a significant proportion of endogenous FA (Klasing 1998, Williams \& Buck 2010). Thus circulating lipoproteins in birds contain a mixture of dietary and stored lipids. Furthermore, this mixture contains high levels of certain FA (some omega-3 and omega-6 FA that are selectively incorporated into the phospholipids of the lipoproteins), likely explaining why other researchers have not found direct dietary signals in plasma using the entire suite of FA present (e.g. R. Käkelä et al. 2005, 2009, Williams \& Buck 2010). To eliminate this bias, we employed a novel approach that compared bird FA profiles with those of potential prey items using a subset of FA that did not include major biosynthetic FA or those typically found in the phospholipid components of circulating lipoproteins.

The present study represents an integrated approach to examine the diets of shearwaters outside of the breeding season by sampling blood from birds and using both SI and FA signature analyses. Our goals were to: (1) investigate inter-annual variability in shearwater diets and provide estimates of prey choices, (2) evaluate dietary overlap between sympatric shearwater species, (3) develop new analytical approaches for analysis of FA data from avian plasma, and (4) compare results between SI and FA analyses.

\section{MATERIALS AND METHODS}

Study site. The present study was conducted in the lower Bay of Fundy around the Grand Manan archipelago (44 42.0' N, 66 49.0' W), New Brunswick, Canada, from mid-July to mid-September, 2005 to 2009. Here, tidal amplitudes range from 4 to $7 \mathrm{~m}$, creating strong tidal currents that produce regions of upwelling where seabirds and marine mammals congregate to feed (Huettmann et al. 2005, Johnston et al. 2005). We captured shearwaters from areas of predictable upwelling during flood tides (Long Eddy rip; $44^{\circ} 49.0^{\prime} \mathrm{N}$, $66^{\circ} 46.0^{\prime} \mathrm{W}$ ) and ebb tides (Clark's Ground and the 
Bulkhead shoals; $44^{\circ} 33.8^{\prime} \mathrm{N}, 66^{\circ} 39.0^{\prime} \mathrm{W}$ ). In the Bay of Fundy, shearwaters typically begin to arrive in late June and early July, and peak in August; most begin southward migration during the first week of September, though some late migrants remain in the area into October and November (Huettmann \& Diamond 2000, L. Murison pers. comm.). Therefore, some blood samples obtained from shearwaters in July may contain dietary signatures from prior to arrival in the Bay of Fundy, but most $(221 / 260 ; 85 \%)$ blood samples were obtained after 1 August.

Sample collection - birds and prey items. Shearwaters were captured using a modified hoop-net during the day, or with spot-lighting and dip nets at night (Whitworth et al. 1997, Ronconi et al. 2010a). In 2005 and 2006, all captures were made without the aid of chum. In 2007-2009, when birds were less abundant and more difficult to capture, chum (whole Atlantic herring Clupea harengus and/or pollock Pollachius virens livers) was used sparingly to aid in capture $(\sim 30 \%)$ of the birds (Ronconi et al. 2010a).

For each shearwater, we measured mass ( $\pm 10 \mathrm{~g})$, wing chord length (WCL; carpal joint to tip of longest primary), bill depth (BD) at 3 locations (on the tube, $\mathrm{BDT}_{\text {; }}$ at the nostril, BDN; and at the gonys, BDG), bill length (BL), and straight tarsus length (TL). Wing chord was measured with a ruler $( \pm 1 \mathrm{~mm})$ while other measurements were taken with dial calipers $( \pm 0.1 \mathrm{~mm})$. Prey remains were collected if birds regurgitated during capture.

Approximately $4.0 \mathrm{ml}$ of whole blood was collected from the tarsal vein using either a 23- or 25-gauge needle and a $5 \mathrm{ml}$ syringe (National Scientific luer-lock plastic syringes). From each sample, $0.5 \mathrm{ml}$ was collected and frozen at $-20^{\circ} \mathrm{C}$ (SI samples) while the remainder was placed in an EDTA collection tube (Becton-Dickinson Vacutainer) and centrifuged at $2000 \times g$ for 10 min (typically within $2 \mathrm{~h}$ of sampling). Plasma was stored in liquid nitrogen until transferred to a $-80^{\circ} \mathrm{C}$ freezer (FA samples). If $<4 \mathrm{ml}$ of blood was collected, the red blood cell portion from the centrifuged EDTA tube was saved for SI analysis. Differences in SI signatures between whole blood and red blood cells are very small (Cherel et al. 2005a) and would not affect the results of the present study. EDTA does not influence SI signatures in bird blood (A. Käkelä et al. 2007).

Fish and invertebrate samples (see Table 1) were collected for SI and FA analyses to develop a library of potential shearwater prey items (see also Supplement 1 available at www.int-res.com/articles/suppl/ m419p267_supp.pdf for complete FA data of selected prey). These included: Atlantic herring, Atlantic mackerel Scomber scombrus, silver hake Merluccius bilinearis, sand lance Ammodytes sp., squid Illex illece- brosus and Loligo pealeii (hereafter referred to as Illex and Loligo, respectively), copepods Calanus finmarchicus, krill Meganyctiphanes norvegica, and pollock livers scavenged from fishing discards. All prey items were collected concurrently with shearwater blood sampling. Prey items were ground to a homogeneous paste and frozen at $-20^{\circ} \mathrm{C}$ before transfer to a $-80^{\circ} \mathrm{C}$ freezer as soon as possible (typically within $1 \mathrm{mo}$ ), until further analysis. Copepods and krill were frozen whole.

Stable isotope sample preparation and analysis. Before isotopic analysis, blood and prey samples were oven-dried at $60^{\circ} \mathrm{C}$ for $24 \mathrm{~h}$. Lipids were removed from prey items by soaking the samples in a $2: 1$ choloroform:methanol solution for $24 \mathrm{~h}$, after which the samples were re-dried and then ground to a fine powder. Sub-samples ( 1 $\mathrm{mg}$ or $0.25 \mathrm{mg})$ of each tissue type were analyzed for signatures of SI of carbon $\left(\delta^{13} \mathrm{C}\right)$ and nitrogen $\left(\delta^{15} \mathrm{~N}\right)$. Isotope ratios were measured by continuous-flow isotope-ratio mass spectrometry (CFIRMS) coupled to a Carlo Erba elemental analyzer (CHNS-O EA1108). SI ratios are expressed in $\delta$ notation as parts per thousand (\%) deviation from standards PeeDee Belemnite (PDB) for ${ }^{13} \mathrm{C}$ and atmospheric nitrogen (AIR) for ${ }^{15} \mathrm{~N}$, according to the following equation: $\delta X=\left[\left(R_{\text {sample }} / R_{\text {standard }}\right)-1\right] \times 1000$, where $X$ is ${ }^{13} \mathrm{C}$ or ${ }^{15} \mathrm{~N}$ and $R$ is the corresponding ratio ${ }^{13} \mathrm{C} /{ }^{12} \mathrm{C}$ or ${ }^{15} \mathrm{~N} /{ }^{14} \mathrm{~N}$. Samples were run with standards interspersed for every 8 samples and results were corrected to these standards (nitrogen standards: ammonium sulphate; carbon standards: sugar, cellulose, or graphite). The error for standard material was $\pm 0.2 \%$ for carbon and $\pm 0.3 \%$ for nitrogen.

Fatty acid sample preparation and analysis. Lipids were extracted from bird plasma and prey items by a modified Folch method (Folch et al. 1957, Koopman et al. 1996). Approximately $1 \mathrm{ml}$ of plasma was extracted for each bird. Due to their small individual size, krill were analyzed in batches of $1 \mathrm{~g}$ (4 to 5 animals). Individual herring and squid were ground and lipids were extracted from a subsample $(\sim 1 \mathrm{~g})$ of homogenates. Because FA analysis generates $>40$ variables per sample, the FA analysis was restricted to potential prey represented by adequate sample sizes: krill $(\mathrm{n}=21)$, squid (Illex, $\mathrm{n}=9$ ), and herring ( $\mathrm{n}=57$ ). These are known major prey items for shearwaters in the Bay of Fundy (Brown et al. 1981).

Extracted total lipids were transformed into FA butyl esters (Koopman et al. 1996) and injected into a Varian 3800 gas chromatograph fitted either with a $30 \mathrm{~m} \times$ $0.25 \mathrm{~mm}$ inner diameter (i.d.) column, coated with $50 \%$ cyanopropyl polysiloxane $(0.25 \mu \mathrm{m}, \mathrm{DB}-23, \mathrm{~J} \& \mathrm{~W}$ Scientific/Agilent Technologies) or a $30 \mathrm{~m} \times 0.25 \mathrm{~mm}$ i.d. column, coated with nitroterephthalic acid modified polyethylene glycol (0.25 $\mu \mathrm{m}$, Zebron FFAP, Phenomenex). 
The injector and detector were held at $250^{\circ} \mathrm{C}$. The temperature programming was as follows: initial temperature of $65^{\circ} \mathrm{C}$, held $2.0 \mathrm{~min}$, ramped at $20.0^{\circ} \mathrm{C} \mathrm{min}^{-1}$ to $165^{\circ} \mathrm{C}$, held $0.4 \mathrm{~min}$, ramped at $2.0^{\circ} \mathrm{C} \min ^{-1}$ to $215^{\circ} \mathrm{C}$, held $6.6 \mathrm{~min}$, ramped at $5.0^{\circ} \mathrm{C} \mathrm{min}{ }^{-1}$ to $250^{\circ} \mathrm{C}$, held $10 \mathrm{~min}$; for a total of a $56 \mathrm{~min}$ run. Identification of FA was made from standard mixtures (Nu Chek Preparations), samples of known composition verified by gas chromatography-mass spectrometry (GC-MS), and from samples earlier identified using silver nitrate chromatography (Iverson 1988). Peak areas were integrated using appropriate response factors (Ackman 1991) with the Galaxie Chromatography Data System (version 1.8.501.1, Varian), and are reported as weightpercent (wt \%) of total FA present. All identified FA were converted to wt $\%$ of the total array and are named according to the IUPAC nomenclature of $\mathrm{X}: \mathrm{Yn}-\mathrm{Z}$, where $\mathrm{X}$ is the number of carbons in the FA, Y is the number of methylene-interrupted double bonds present in the chain, and $\mathrm{n}-\mathrm{z}$ denotes the position of the last double bond relative to the methyl terminus. Values for wt $\%$ are presented as mean \pm SE unless otherwise noted. All FA data were arcsine-transformed prior to statistical analyses to reduce heterogeneity of variances (Zar 1996).

Data analysis. Body condition indices: Physiological processes associated with nutritional state are known to affect SI signatures (Gannes et al. 1998) such that nutritional stress may lead to $\delta^{15} \mathrm{~N}$ enrichment (Cherel et al. 2005a). Body condition indices can be incorporated into analyses of SI data to account for nutritional stress (Williams et al. 2007b). Body size indices (Rising \& Somers 1989, Williams et al. 2007b) were developed for each shearwater species separately by performing a principal components analysis (PCA) on the morphological measurements and extracting the first principal component (PC1). We used the residuals of mass regressed against PC1 as an index of body condition (Green 2001, Williams et al. 2007b); positive and negative indices indicate heavier or lighter individuals, respectively, than would be expected based on body size.

Stable isotope signatures: Differences in signatures among prey items were assessed by multivariate analysis of variance (MANOVA) comparing both isotopes simultaneously, and tests of between-subject effects allowed for comparison of $\delta^{13} \mathrm{C}$ and $\delta^{15} \mathrm{~N}$ contribution separately. For prey species that were sampled in multiple years, analysis tested for year effects on each species separately and included fork length as a covariate for herring because $\delta^{13} \mathrm{C}$ and $\delta^{15} \mathrm{~N}$ vary with herring size (R. A. Ronconi unpubl. data).

Generalized linear models (GLM) were used to test factors affecting SI signatures $\left(\delta^{13} \mathrm{C}\right.$ and $\delta^{15} \mathrm{~N}$ were analyzed separately) in shearwater blood. Candidate models were selected a priori from combinations of the following variables: species, year (2005 to 2009), capture site (Long Eddy, Bulkhead, and other locations pooled), day-of-year (control for seasonal effects), and body condition index. Candidate models included all possible combinations of variables without interaction terms. Model selection used Akaike's information criterion (AIC) and AIC 'weight', $w_{i}$, the probability that a candidate model is the best model given the data and models tested (Burnham \& Anderson 2002).

Isotope mixing models: Two dual-isotope $\left(\delta^{13} \mathrm{C}\right.$ and $\delta^{15} \mathrm{~N}$ ) and multi-source SI mixing models were used to quantify the relative contribution of prey items in the diets of shearwaters: IsoSource version 1.3.1 (Phillips \& Gregg 2003) and the newer MixSIR version 1.0.4 (Moore \& Semmens 2008, Semmens et al. 2009). The former has been widely applied to dietary studies using mean isotopic values of predators and prey items, while the latter employs a Bayesian approach that accounts for variance (rather than means) in both predator and prey isotopic values. There has been little direct comparison of these methods. To simplify the mixing models, we limited the potential prey items to those items that are known to occur in shearwater diets based on stomach contents from the Bay of Fundy (Brown et al.1981): herring, squid (Illex), krill, mackerel, sand lance, and pollock livers. Fractionation values were obtained from experimental and captive bird studies that reported discrimination factors between lipidextracted whole prey and bird blood (Cherel et al. 2005b, Williams et al. 2007a): average fractionation values $(\mathrm{n}=5)$ between whole prey and blood were $+2.75 \pm 0.40 \% \mathrm{SD}\left(\delta^{15} \mathrm{~N}\right)$ and $-0.06 \pm 0.71 \%{ }^{13}\left(\delta^{13} \mathrm{C}\right)$.

Variation in bird plasma fatty acid signatures: FA data are inherently difficult to analyze because of their dependent nature (proportional fractional data) and because FA data sets rarely meet assumptions of normality (Budge et al. 2006). An alternate approach is to submit the data to PRIMER, a multivariate analysis program primarily designed for examination of ecological communities but appropriate for FA data (e.g. Budge et al. 2007). Use of PRIMER requires few assumptions about the data set, making it useful for complex, non-normal data (Clarke \& Gorley 2006). The complete FA data set, including all 47 FA components from the shearwaters, was submitted to PRIMER, and a Bray-Curtis resemblance matrix was generated. Relationships among bird data points were investigated using multi-dimensional scaling (MDS) and analysis of similarities (ANOSIM) (Clarke 1993), testing for year and species effects at a 0.01 significance level. As ANOSIM revealed a significant year effect (see 'Results: Variation in bird fatty acid signatures'), species differences were also tested separately for each year. We also used the similarity percentages pro- 
cedure (SIMPER) to identify which FA were most responsible for the observed variation between years.

Inference of diet using fatty acid data: To obtain an overall view of the relationships between FA signatures of birds and their 3 main potential prey items (herring, krill and squid Illex), all FA data (birds and prey) were submitted to PRIMER for MDS analysis. This analysis revealed little overlap between bird samples and data from their prey, which was not surprising given that bird blood lipids are known to contain a mixture of dietary, stored, and endogenous FA (see 'Introduction'). We reduced the influence of nondietary constituents by excluding those FA with a higher likelihood of being associated with lipoprotein phospholipids. Unfortunately, there are few data on lipoprotein FA composition in wild animals, and there have been no studies aimed specifically at quantifying the major non-dietary portomicron FA in birds. We selected our subset of FA to be excluded from the analysis using data obtained from lipoproteins in seals (Cooper et al. 2005) under the assumption that the phospholipid components of transport proteins show similarities across animal groups (we recognize the need for a caveat here; see 'Discussion'). The FA excluded from the subset were 14:0, 16:0, 16:1n-7, 18:0, 18:1n-9, 20:4n-6, 20:5n-3, 22:5n-3, and 22:6n-3. This modified data set of 38 FA was renormalized and then arcsine-transformed as above (see 'FA sample preparation and analysis'), and submitted to PRIMER for preliminary MDS analysis.

Without calibration coefficients for shearwater metabolism of FA and a full prey library, we could not quantitatively estimate diet (Iverson et al. 2004), but we did wish to obtain a qualitative view of the relative consumption of herring, krill, and squid by shearwaters using their blood lipids. We used discriminant function analysis (DFA) to create discriminant functions (DFs) based on prey FA composition to classify each bird (in essence, 'forcing' each bird to be classified as one of the prey species, following Connan et al. 2005). As the number of FA variables was greater than the sample size of the smallest group, the FA subset was first subjected to PCA in order to reduce the number of variables. The PCA was conducted using varimax rotation and a maximum of 50 iterations for convergence. DFA was then carried out on the 10 principal components (PCs) generated by the PCA, using only the data from the prey items to construct DFs which were then used to classify all samples. The ability of the DFA to distinguish the prey species was tested using leave-one-out classification, with prior probabilities computed from group sizes. Finally, the ANOSIM and SIMPER analyses were repeated on the bird data alone using the subset of 38 FA to test for annual and species differences.

\section{RESULTS}

Between 21 July and 16 September during the 5 years of the present study, we captured a total of 331 greater and 23 sooty shearwaters, and obtained blood samples from 231 and 22 individuals, respectively. Mean $( \pm$ SD) mass for greater shearwaters was $908 \pm$ $136 \mathrm{~g}(\mathrm{n}=328)$ and varied significantly among years $\left(F_{4,323}=7.77, \mathrm{p}<0.001\right)$ due to significantly higher masses recorded in 2005 (mean: 1008 g; Tukey's post hoc: $\mathrm{p}<0.001)$. Sooty shearwaters weighed $995 \pm 127 \mathrm{~g}$ ( $\mathrm{n}=23$ ), with no significant differences among years $\left(F_{4,18}=0.96, \mathrm{p}=0.456\right)$.

Of all captured birds, only 17 individuals (3 sooty and 14 greater shearwaters) regurgitated prey samples. Of the 17 samples, most $(88 \%, \mathrm{n}=15)$ contained herring or other unidentified fish, $12 \%(\mathrm{n}=2)$ contained krill, and 1 sample was not identifiable. One regurgitate sample contained both krill and herring. The krill regurgitate from 2 individuals consisted of approximately 6 and 40 individual krill. Seven relatively intact herring samples collected from 4 individuals had a mean $( \pm \mathrm{SD})$ length of $13.9 \pm 1.9 \mathrm{~cm}$. The maximum mass of a regurgitated herring was $57 \mathrm{~g}$ from a partial fish sample.

For greater and sooty shearwaters, PC1 (body size index) from a PCA on shearwater morphometrics explained $53.8 \%$ and $45.7 \%$ of the variance of each species respectively. Eigenvalues for PC1 of greater shearwaters were 0.652 (TL), 0.529 (BL), 0.845 (BDT), and 0.857 (BDN), suggesting that all 4 measurements contributed to the body size index (WCL measurements omitted because birds were still moulting primaries, BDG measurements omitted due to missing data). For sooty shearwaters, eigenvalues of PC1 were 0.511 (TL), 0.667 (BL), 0.794 (BDT), 0.822 (BDN), 0.820 (BDG), and 0.236 (WCL), suggesting the importance of all measurements except WCL. The regression of mass on body size index (PC1) was significant for greater shearwaters $\left(F_{1,300}=69.2, \mathrm{p}<0.001, \mathrm{r}^{2}=0.187\right)$ and nearly significant for sooty shearwaters $\left(F_{1,21}=3.9, \mathrm{p}=\right.$ $0.062, \mathrm{r}^{2}=0.157$ ). Hereafter, residuals of mass on PC1 are used as a body condition index (BCI).

\section{Isotopic signatures of prey}

Comparisons among prey items showed significant differences in both $\delta^{13} \mathrm{C}$ and $\delta^{15} \mathrm{~N}$ among species (MANOVA: $F_{12,520}=92.126, \mathrm{p} \leq 0.001$; Fig. 1, Table 1). Hake $(\mathrm{n}=2)$ and sand lance $(\mathrm{n}=3)$ were omitted from the analysis due to low sample sizes but are presented in the tables and figures for comparison. Post hoc comparisons found significant differences $(p<0.05)$ between all prey types for at least one of $\delta^{13} \mathrm{C}$ or $\delta^{15} \mathrm{~N}$, 


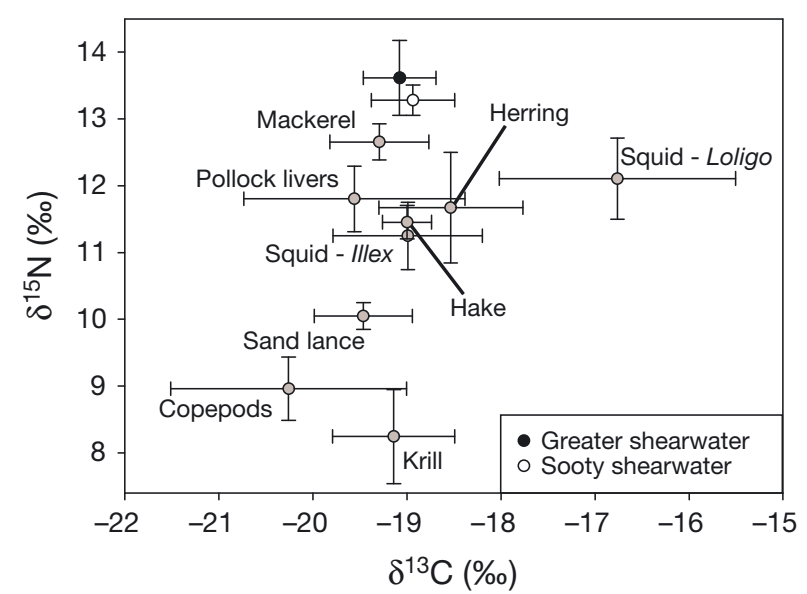

Fig. 1. Puffinus gravis and P. griseus. Stable isotope signatures (mean $\pm \mathrm{SD}$ ) of shearwaters and selected fish and invertebrates from the Bay of Fundy, 2005 to 2009

except for Illex versus pollock livers and Illex versus herring (Table 1). Tukey's HSD tests identified the following homogeneous subsets based on $\delta^{13} \mathrm{C}$ (copepods-pollock livers; krill-mackerel-Illex-pollock livers; krill-mackerel-Illex-herring; Loligo) and $\delta^{15} \mathrm{~N}$ (copepods-krill; herring-Illex-pollock livers; herring-pollock livers-Loligo; Loligo-mackerel).

Herring isotopic signatures showed significant interannual variability (MANOVA: $5 \mathrm{yr}, F_{8,216}=10.981, \mathrm{p} \leq$ $0.001, \delta^{13} \mathrm{C}: \mathrm{p}<0.001, \delta^{15} \mathrm{~N}: \mathrm{p}=0.001$; Fig. 2) with fish length included as a significant covariate $(p<0.001)$, thus controlling for fish size. Note that the largest differences occurred in 2009 when only small fish (7.6 to $14.3 \mathrm{~cm}$ ) were sampled; therefore, overall herring iso-

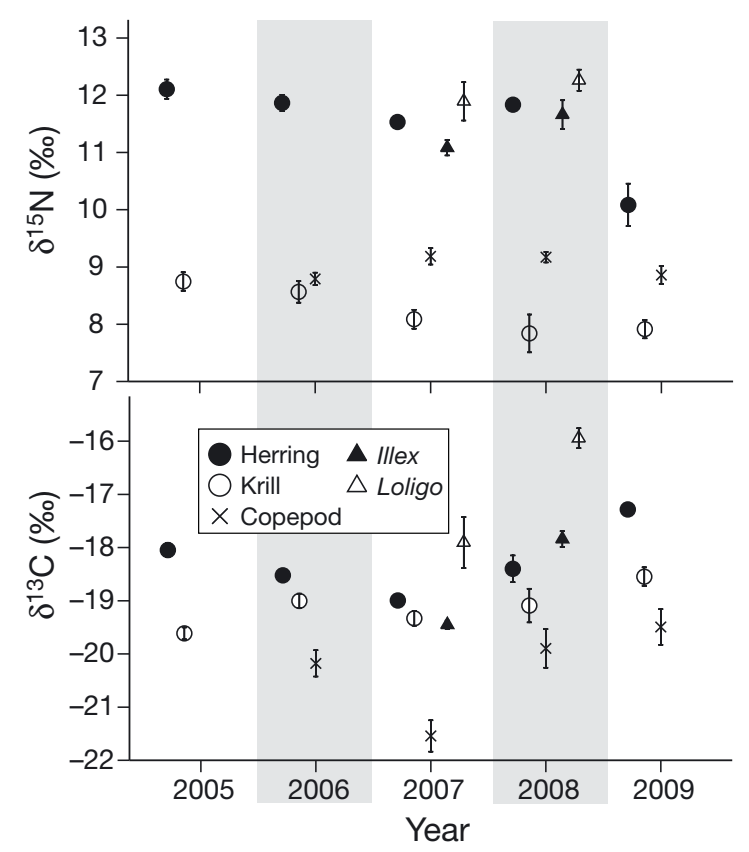

Fig. 2. Clupea harengus, Meganyctiphanes norvegica, Calanus finmarchicus, Illex illecebrosus, and Loligo pealeii. Inter-annual variability in stable isotope signatures (mean \pm $\mathrm{SE}$ ) for herring, krill, copepods, northern short-fin squid, and long-fin squid. Note that low $\delta^{15} \mathrm{~N}$ values for herring in 2009 are due to sampling of only small fish $(<14 \mathrm{~cm})-$ see 'Results' for details

tope values were used in 2009 mixing models (see below) rather than 2009 values, which were not representative of the herring population. Similarly, krill signatures showed significant year effects $\left(5 \mathrm{yr}: F_{8,102}=\right.$ 5.462, $\left.\mathrm{p}<0.001, \delta^{13} \mathrm{C}: \mathrm{p}<0.001, \delta^{15} \mathrm{~N}: \mathrm{p}=0.007\right)$. There

Table 1. Puffinus gravis and P. griseus. Stable isotope values of shearwater blood samples and selected fish and invertebrates from the Bay of Fundy, 2005 to 2009. Sample size (n) for shearwaters is for stable isotope values only (sample size for mass includes all birds captured during the 5 yr study - see 'Results'). Tukey's HSD homogeneous subsets (HS) are results from MANOVA comparing $\delta^{13} \mathrm{C}$ and $\delta^{15} \mathrm{~N}$ among shearwater prey species (sand lance and hake excluded due to low sample size). na $=$ not applicable, $\mathrm{nd}=$ not determined. Letters a to $d$ indicate groups of species belonging to each of 4 homogeneous subsets for $\delta^{13} \mathrm{C}$ and $\delta^{15} \mathrm{~N}$ separately

\begin{tabular}{|c|c|c|c|c|c|c|c|}
\hline \multirow[t]{2}{*}{ Species } & \multirow[t]{2}{*}{$\mathrm{n}$} & \multirow[t]{2}{*}{$\begin{array}{c}\text { Length }(\mathrm{cm}) \\
\text { mean } \pm \mathrm{SD}\end{array}$} & \multirow[t]{2}{*}{$\begin{array}{c}\text { Mass }(\mathrm{g}) \\
\text { mean } \pm \mathrm{SD}\end{array}$} & \multicolumn{2}{|c|}{$\begin{array}{l}\text { Concentration }(\%) \\
\text { mean } \pm \mathrm{SD}\end{array}$} & \multicolumn{2}{|c|}{$\begin{array}{c}\text { Tukey's HSD } \\
\text { HS }\end{array}$} \\
\hline & & & & $\delta^{13} \mathrm{C}$ & $\delta^{15} \mathrm{~N}$ & $\delta^{13} \mathrm{C}$ & $\delta^{15} \mathrm{~N}$ \\
\hline Greater shearwater Puffinus gravis & 231 & na & $908 \pm 136$ & $-19.1 \pm 0.4$ & $13.6 \pm 0.6$ & na & na \\
\hline Sooty shearwater Puffinus griseus & 22 & na & $995 \pm 127$ & $-18.9 \pm 0.4$ & $13.3 \pm 0.2$ & na & na \\
\hline Copepods Calanus finmarchicus & 50 & na & na & $-20.3 \pm 1.3$ & $9.0 \pm 0.5$ & $\mathrm{a}$ & $\mathrm{a}$ \\
\hline Northern krill Meganyctiphanes norvegica & 57 & na & na & $-19.3 \pm 0.5$ & $8.3 \pm 0.7$ & $\mathrm{~b}, \mathrm{c}$ & $\mathrm{a}$ \\
\hline Atlantic herring Clupea harengus & 115 & $17.7 \pm 5.3$ & $76.0 \pm 66.6$ & $-18.5 \pm 0.8$ & $11.7 \pm 0.8$ & $\mathrm{C}$ & $\mathrm{b}, \mathrm{c}$ \\
\hline Northern short-fin squid Illex illecebrosus & 14 & $14.0 \pm 5.1$ & $69.8 \pm 65.1$ & $-19.0 \pm 0.8$ & $11.2 \pm 0.5$ & $\mathrm{~b}, \mathrm{c}$ & $\mathrm{b}$ \\
\hline Long-fin squid Loligo pealeii & 12 & $11.4 \pm 2.6$ & $39.8 \pm 18.2$ & $-16.8 \pm 1.3$ & $12.1 \pm 0.6$ & $\mathrm{~d}$ & $\mathrm{c}, \mathrm{d}$ \\
\hline Atlantic mackerel Scomber scombrus & 7 & $23.7 \pm 1.1$ & $137.8 \pm 17.3$ & $-19.3 \pm 0.5$ & $12.7 \pm 0.3$ & $\mathrm{~b}, \mathrm{c}$ & $\mathrm{d}$ \\
\hline Sand lance Ammodytes sp. & 3 & $9.3 \pm 0.2$ & $1.7 \pm 0.4$ & $-19.5 \pm 0.5$ & $10.0 \pm 0.2$ & nd & nd \\
\hline Silver hake Merluccius bilinearis & 2 & $22.0 \pm 0.7$ & $77.2 \pm 2.3$ & $-18.9 \pm 0.2$ & $11.4 \pm 0.2$ & nd & nd \\
\hline Pollock Pollachius virens livers & 13 & na & na & $-19.6 \pm 1.2$ & $11.8 \pm 0.5$ & $a, b$ & $\mathrm{~b}, \mathrm{c}$ \\
\hline
\end{tabular}


were also significant changes in isotopic signatures of copepods ( 4 yr: $F_{6,90}=4.257, \mathrm{p}=0.001, \delta^{13} \mathrm{C}: \mathrm{p}=0.001$, $\left.\delta^{15} \mathrm{~N}: \mathrm{p}=0.059\right)$, Illex squid (2 yr: $F_{2,11}=50.209, \mathrm{p}<$ $\left.0.001, \delta^{13} \mathrm{C}: \mathrm{p}<0.001, \delta^{15} \mathrm{~N}: \mathrm{p}=0.049\right)$, and Loligo squid $\left(2\right.$ yr: $F_{2,9}=14.192, \mathrm{p}=0.002, \delta^{13} \mathrm{C}: \mathrm{p}=0.002, \delta^{15} \mathrm{~N}: \mathrm{p}=$ 0.324). Other prey items lacked sufficient sample size to examine inter-annual variability. This suggests widespread inter-annual variability in isotopic signatures in the prey base of the Bay of Fundy (Fig. 2). With the exception of krill in 2005, inter-annual patterns in $\delta^{13} \mathrm{C}$ signatures appear to co-vary among prey types, with lowest values in 2007 (Fig. 2). Conversely, patterns in $\delta^{15} \mathrm{~N}$ varied less predictably but were generally lower for most prey types in 2007.

\section{Isotopic signatures of shearwaters}

Over the 5 yr there were inter-annual and inter-specific differences in stable isotope signatures of shearwater blood (Fig. 3). Four models for whole-blood $\delta^{15} \mathrm{~N}$ values were included in the $90 \%$ confidence set (Table 2). Year, site, and BCI were included in the top 3 models but species was included in only two of these models. Species effects on $\delta^{15} \mathrm{~N}$ showed that greater shearwaters consistently fed at a slightly higher trophic level than sooty shearwaters in each year (Fig. 3).

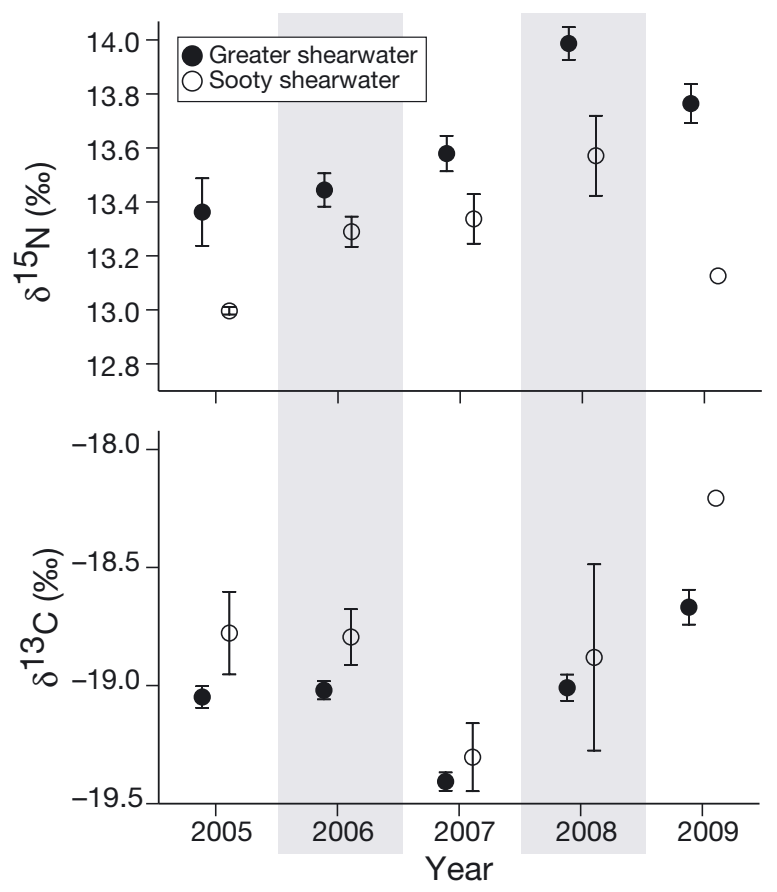

Fig. 3. Puffinus gravis and P. griseus. Inter-annual variability in stable isotope signatures (mean $\pm \mathrm{SE}$ ) for shearwater blood samples
Table 2. Puffinus gravis and P. griseus. $90 \%$ confidence set (cumulative $w_{i}=0.90$ ) of generalized linear models that explain variation in $\delta^{15} \mathrm{~N}$ and $\delta^{13} \mathrm{C}$ from blood of shearwaters captured in the Bay of Fundy, 2005 to 2009. The model set is presented in ascending order of the change in Akaike's information criterion $(\triangle \mathrm{AIC})$, with the lowest value being the best fit to the data. Parameters included in the models are year, species (greater and sooty shearwaters), site (location of capture), body condition index (BCI), and day of year. $w_{i}=$ model weight, $\mathrm{K}=$ number of parameters in the model

\begin{tabular}{|c|c|c|c|c|}
\hline Model & $\mathrm{K}$ & $\begin{array}{l}\text { Log } \\
\text { likelihood }\end{array}$ & $\Delta \mathrm{AIC}$ & $w_{i}$ \\
\hline \multicolumn{5}{|l|}{$\delta^{15} \mathbf{N}$} \\
\hline Year, Species, Site, BCI & 9 & -165.75 & 0.00 & 0.32 \\
\hline Year, Site, BCI & 8 & -166.80 & 0.09 & 0.31 \\
\hline $\begin{array}{l}\text { Year, Species, Site, BCI, } \\
\text { Day of year }\end{array}$ & 10 & -165.30 & 1.10 & 0.18 \\
\hline $\begin{array}{l}\text { Year, Site, BCI, Day of year } \\
\boldsymbol{\delta}^{13} \mathbf{C}\end{array}$ & 9 & -166.50 & 1.50 & 0.15 \\
\hline Year, Species & 6 & -76.65 & 0.00 & 0.25 \\
\hline Year, Species, Day of year & 7 & -75.74 & 0.17 & 0.23 \\
\hline Year, Species, BCI & 7 & -76.38 & 1.47 & 0.12 \\
\hline Year, Species, BCI, Day of year & 8 & -75.62 & 1.94 & 0.09 \\
\hline Year, Species, Site, Day of year & 9 & -74.67 & 2.04 & 0.09 \\
\hline Year, Species, Site & 8 & -76.19 & 3.08 & 0.05 \\
\hline Year, Day of year & 6 & -78.41 & 3.52 & 0.04 \\
\hline $\begin{array}{l}\text { Year, Species, Site, BCI, } \\
\text { Day of year }\end{array}$ & 10 & -74.58 & 3.86 & 0.04 \\
\hline
\end{tabular}

The site effect suggested that birds captured at the Long Eddy tidal rip had higher $\delta^{15} \mathrm{~N}$ values compared to birds captured at the Bulkhead. This occurred in 4 out of 5 years (comparisons were not possible in 2005 when birds were at 1 site). The mean difference between sites $(0.36,0.13,0.15$, and $0.30 \%$ in 2006,2007 , 2008 , and 2009 respectively) represented a similar difference in trophic level as was observed between species, which differed between 0.15 and $0.64 \%$ in $\delta^{15} \mathrm{~N}$, depending on the year.

BCI were generally positively correlated with $\delta^{15} \mathrm{~N}$, suggesting that heavier birds had been foraging at higher trophic levels. However, this trend was not significant for greater shearwaters when all years were pooled $\left(F_{1,225}=2.57, \mathrm{p}=0.110, \mathrm{r}^{2}=0.011\right)$ and was only marginally significant in 3 out of 5 years separately: $2005\left(F_{1,30}=3.70, \mathrm{p}=0.064, \mathrm{r}^{2}=0.110\right), 2006\left(F_{1,69}=\right.$ $\left.0.187, \mathrm{p}=0.667, \mathrm{r}^{2}=0.003\right), 2007\left(F_{1,48}=9.89, \mathrm{p}=0.003\right.$, $\left.\mathrm{r}^{2}=0.171\right), 2008\left(F_{1,51}=2.77, \mathrm{p}=0.102, \mathrm{r}^{2}=0.051\right), 2009$ $\left(F_{1,19}=0.39, \mathrm{p}=0.583, \mathrm{r}^{2}=0.020\right)$. The relationship was not significant for sooty shearwaters $\left(F_{1,20}=0.057, \mathrm{p}=\right.$ $\left.0.814, \mathrm{r}^{2}=0.003\right)$.

The models for whole-blood $\delta^{13} \mathrm{C}$ values included 8 in the $90 \%$ confidence set (Table 2), suggesting considerable model uncertainty. Nevertheless, year and species were included in each of the top 6 models and were the only 2 factors in the overall best model (AIC 
$\left.W_{i}=0.25\right)$. In each year, $\delta^{13} \mathrm{C}$ values were slightly higher for sooty shearwaters (Fig. 3). These small, yet consistent, differences between species suggest subtle partitioning of diet. The year effect on $\delta^{13} \mathrm{C}$ was more pronounced, with values in 2007 being between 0.37 and $0.75 \%$ lower than other years, and 2009 being between 0.35 and $0.75 \%$ higher than other years. The day-of-year effect, which was included in the secondbest model (Table 2), was weak but statistically significant $\left(F_{1,251}=7.17, \mathrm{p}=0.008, \mathrm{r}^{2}=0.028\right)$, showing increasing $\delta^{13} \mathrm{C}$ values throughout the season.

\section{Estimates of shearwater diets using stable isotopes}

Mixing models were used to estimate the contribution of different prey items to shearwater diets. In general, there was qualitative agreement between IsoSource and MixSIR models, suggesting that krill, herring, and squid were the primary prey items for both shearwater species in most years (Table 3, Fig. 4). Krill estimates ranged from 18 to $49 \%$ of total diet for sooty shearwaters and 10 to $43 \%$ for greater shearwaters. Herring estimates for greater and sooty shearwaters were 3 to $44 \%$ and 6 to $46 \%$ of total diet, respectively. For both shearwater species, squid contributed more to diets in 2007-2009, resulting in a decrease in reliance on herring and krill during those years. Mackerel and pollock livers typically each contributed $<10 \%$ to shearwater diet estimates, but were more important in greater shearwater diets, especially in 2008. One major discrepancy between the models occurred in estimates of sand lance contribution. MixSIR indicated 12 to $20 \%$ contribution for sooty shearwaters but only 2 to $14 \%$ for greater shearwaters, yet IsoSource models suggested the opposite: 12 to $21 \%$ contribution for greater shearwaters but only 2 to $18 \%$ for sooty shearwaters.

Species-specific model estimates revealed subtle differences in diet (Table 3, Fig. 4). IsoSource estimates

Table 3. Puffinus gravis and P. griseus. Model estimates of the contribution of different prey items to the diet of greater and sooty shearwaters using different mixing models. Values in bold indicate the top 2 prey sources contributing to the diet (or top 3 choices if values nearly match). MixSIR (Moore \& Semmens 2008) outputs median and 5th and 95th percentiles. IsoSource (Phillips \& Gregg 2003) outputs mean and 1 and $99 \%$ confidence limits

\begin{tabular}{|c|c|c|c|c|c|c|c|}
\hline \multirow{2}{*}{$\begin{array}{l}\text { Model type } \\
\text { Data set }\end{array}$} & \multirow[t]{2}{*}{$\mathrm{n}$} & \multicolumn{6}{|c|}{ Prey source } \\
\hline & & Krill & Herring & Squid (Illex) & Mackerel & Sand lance & Pollock livers \\
\hline \multicolumn{8}{|l|}{ MixSIR } \\
\hline \multicolumn{8}{|c|}{ Greater shearwater } \\
\hline 2005 & 34 & $0.43(0.37-0.48)$ & $0.44(0.37-0.51)$ & $0.03(0.00-0.10)$ & $0.03(0.00-0.10)$ & $0.02(0.00-0.08)$ & $0.03(0.00-0.09)$ \\
\hline 2006 & 71 & $0.28(0.21-0.35)$ & $0.36(0.31-0.42)$ & $0.13(0.02-0.26)$ & $0.07(0.01-0.16)$ & $0.09(0.01-0.21)$ & $0.05(0.01-0.12)$ \\
\hline 2007 & 52 & $0.14(0.07-0.22)$ & $0.08(0.01-0.19)$ & $0.57(0.43-0.66)$ & $0.09(0.01-0.23)$ & $0.05(0.00-0.18)$ & $0.04(0.00-0.13)$ \\
\hline 2008 & 53 & $0.21(0.02-0.24)$ & $0.03(0.00-0.12)$ & $0.24(0.06-0.41)$ & $0.44(0.01-0.55)$ & $0.03(0.00-0.28)$ & $0.06(0.01-0.39)$ \\
\hline 2009 & 21 & $0.16(0.06-0.24)$ & $0.16(0.02-0.32)$ & $0.31(0.16-0.45)$ & $0.12(0.02-0.28)$ & $0.14(0.02-0.31)$ & $0.08(0.01-0.21)$ \\
\hline Years pooled & 231 & $0.21(0.14-0.27)$ & $0.45(0.41-0.48)$ & $0.04(0.00-0.12)$ & $0.11(0.04-0.19)$ & $0.11(0.02-0.23)$ & $0.07(0.01-0.13)$ \\
\hline \multicolumn{8}{|c|}{ Sooty shearwater } \\
\hline 2005 & 3 & $0.35(0.1-0.05)$ & $0.15(0.02-0.35)$ & $0.08(0.01-0.28)$ & $0.05(0.00-0.18)$ & $0.19(0.02-0.61)$ & $0.08(0.00-0.27)$ \\
\hline 2006 & 9 & $0.32(0.15-0.43)$ & $0.21(0.05-0.37)$ & $0.09(0.01-0.28)$ & $0.10(0.01-0.28)$ & $0.12(0.01-0.43)$ & $0.08(0.01-0.27)$ \\
\hline 2007 & 7 & $0.20(0.07-0.33)$ & $0.15(0.02-0.37)$ & $0.15(0.02-0.41)$ & $0.11(0.01-0.29)$ & $0.20(0.02-0.49)$ & $0.01(0.01-0.28)$ \\
\hline 2008 & 2 & $0.18(0.04-0.31)$ & $0.15(0.01-0.41)$ & $0.16(0.02-0.41)$ & $0.11(0.01-0.33)$ & $0.18(0.02-0.48)$ & $0.12(0.01-0.37)$ \\
\hline 2009 & 1 & $0.27(0.08-0.45)$ & $0.13(0.01-0.42)$ & $0.16(0.01-0.45)$ & $0.08(0.01-0.27)$ & $0.12(0.01-0.46)$ & $0.09(0.01-0.33)$ \\
\hline Years pooled & 22 & $0.24(0.13-0.35)$ & $0.20(0.06-0.32)$ & $0.21(0.04-0.38)$ & $0.08(0.01-0.22)$ & $0.18(0.03-0.41)$ & $0.06(0.01-0.19)$ \\
\hline \multicolumn{8}{|l|}{ IsoSource } \\
\hline \multicolumn{8}{|c|}{ Greater shearwater } \\
\hline 2005 & 34 & $0.32(0.08-0.46)$ & $0.34(0.27-0.44)$ & $0.08(0.00-0.28)$ & $0.05(0.00-0.17)$ & $0.16(0.00-0.56)$ & $0.05(0.00-0.19)$ \\
\hline 2006 & 71 & $0.29(0.13-0.42)$ & $0.32(0.15-0.47)$ & $0.10(0.00-0.34)$ & $0.10(0.00-0.33)$ & $0.12(0.00-0.39)$ & $0.08(0.00-0.28)$ \\
\hline 2007 & 52 & $0.14(0.00-0.32)$ & $0.15(0.00-0.41)$ & $0.20(0.00-0.66)$ & $0.14(0.00-0.44)$ & $0.21(0.00-0.56)$ & $0.16(0.00-0.48)$ \\
\hline 2008 & 53 & $0.10(0.00-0.23)$ & $0.20(0.00-0.50)$ & $0.15(0.00-0.34)$ & $0.18(0.00-0.47)$ & $0.17(0.00-0.41)$ & $0.19(0.00-0.48)$ \\
\hline 2009 & 21 & $0.16(0.01-0.27)$ & $0.24(0.00-0.63)$ & $0.27(0.01-0.51)$ & $0.11(0.00-0.33)$ & $0.13(0.00-0.39)$ & $0.10(0.00-0.31)$ \\
\hline Years pooled & 231 & $0.17(0.01-0.31)$ & $0.27(0.01-0.49)$ & $0.23(0.00-0.70)$ & $0.10(0.00-0.34)$ & $0.14(0.00-0.45)$ & $0.09(0.00-0.30)$ \\
\hline \multicolumn{8}{|c|}{ Sooty shearwater } \\
\hline 2005 & 3 & $0.49(0.45-0.55)$ & $0.46(0.45-0.50)$ & $0.01(0.00-0.05)$ & $0.00(0.00-0.00)$ & $0.03(0.00-0.10)$ & $0.01(0.00-0.05)$ \\
\hline 2006 & 9 & $0.37(0.29-0.44)$ & $0.48(0.40-0.57)$ & $0.04(0.00-0.14)$ & $0.04(0.00-0.14)$ & $0.04(0.00-0.16)$ & $0.03(0.00-0.12)$ \\
\hline 2007 & 7 & $0.24(0.04-0.39)$ & $0.27(0.04-0.55)$ & $0.13(0.00-0.44)$ & $0.12(0.00-0.42)$ & $0.16(0.00-0.54)$ & $0.09(0.00-0.30)$ \\
\hline 2008 & 2 & $0.19(0.01-0.31)$ & $0.21(0.00-0.54)$ & $0.21(0.00-0.40)$ & $0.11(0.00-0.34)$ & $0.18(0.00-0.51)$ & $0.11(0.00-0.34)$ \\
\hline 2009 & 1 & $0.34(0.29-0.38)$ & $0.06(0.00-0.22)$ & $0.54(0.42-0.64)$ & $0.02(0.00-0.08)$ & $0.02(0.00-0.09)$ & $0.02(0.00-0.07)$ \\
\hline Years pooled & 22 & $0.29(0.19-0.38)$ & $0.41(0.21-0.58)$ & $0.13(0.00-0.46)$ & $0.05(0.00-0.18)$ & $0.08(0.00-0.27)$ & $0.04(0.00-0.16)$ \\
\hline
\end{tabular}


(Fig. 4a) suggested that sooty shearwaters rely primarily on krill and herring, compared to greater shearwater diets, which may include slightly higher proportions of other prey items such as mackerel, squid, sand lance, and fisheries discards (pollock livers). The broad histogram distribution for sand lance in the MixSIR model (Fig. 4c) suggested a great deal of uncertainty in the contribution of sand lance and mackerel to sooty

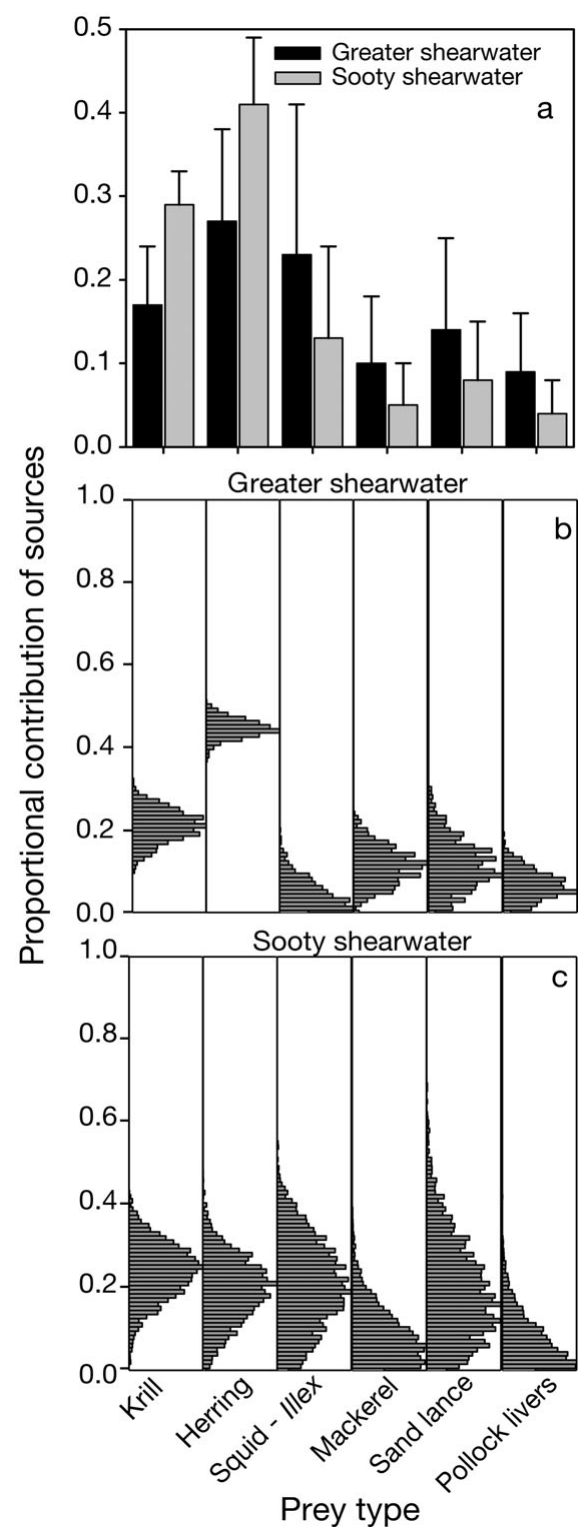

Fig. 4. Puffinus gravis and P. griseus. Plots of data model solutions using (a) IsoSource and $(b, c)$ MixSIR mixing model to estimate contribution of different prey items in shearwater diets. Shearwater data were pooled across years for each species and correspond to output from Table 3. Bars in (a) show mean \pm SD. Histograms $(b, c)$ show the posterior Bayesian model estimates for prey contributions whereby the 50th percentile corresponds to the most likely estimate of contribution to diet shearwater diets. Moreover, bimodal and skewed histograms for greater shearwaters in 2008 (Fig. 5) illustrate other aspects of uncertainty in diet estimation.

\section{Variation in bird fatty acid signatures}

A total of 112 greater and 15 sooty shearwaters were included in the FA analyses of plasma samples obtained during the first 3 yr of the study (Supplement 1 at www.int-res.com/articles/suppl/m419p267_supp.pdf). The MDS plot revealed strong differences in FA signatures (using all FAs) from shearwater blood across years (Fig. 6), and the stress value of 0.2 indicated that the model was confident in the placement of all points relative to each other (Clarke \& Gorley 2006). These apparent differences were confirmed by ANOSIM, with all years (2005-2007) being significantly different from each other $(\mathrm{p}<0.01$; global $\mathrm{R}=0.301)$. The FA with the greatest contributions to this variation were mostly monounsaturates (18:1n-11, 22:1n-11, 20:1n-9, 24:1n-11). No single FA accounted for $>9 \%$ of the variation between years, indicating that differences were occurring in the entire FA signature. There were no significant differences between the 2 species in FA signature, either in the data set as a whole (global $\mathrm{R}=-0.109$ ) or for each year tested separately (all: $\mathrm{p}>0.1$ ). When this analysis was repeated on the subset of $38 \mathrm{FA}$, the differences among years were still significant $(p<0.01$; global $R=0.291$ ), there were still no significant differences between the 2 species ( $p>0.1$ ), and the FA most responsible for the differences between years were still members of the $>18 \mathrm{C}$ monounsaturated group.

\section{Inference of diet using fatty acid data}

The MDS plot (not shown) of birds and their potential prey items (krill, herring, and squid), incorporating all FA, revealed significant structure, with prey items well-distinguished from each other, and no overlap between birds and prey. The 2D stress value of 0.1 indicated that the model had relatively low confidence in placement of the points relative to each other. The reduced suite of 38 FAs yielded an MDS plot with less separation between the shearwaters and their prey. The stress value of 0.16 indicated that this model had greater confidence in its placement of samples than the model incorporating the entire suite of FA, lending support for our use of the reduced FA suite for further analyses.

The PCA yielded 10 PCs with eigenvalues $>1$; together these explained $>74 \%$ of the variation in the data. The DFA produced 2 significant functions, DF1 and DF2, with eigenvalues of 14.8 and 3.3, respec- 


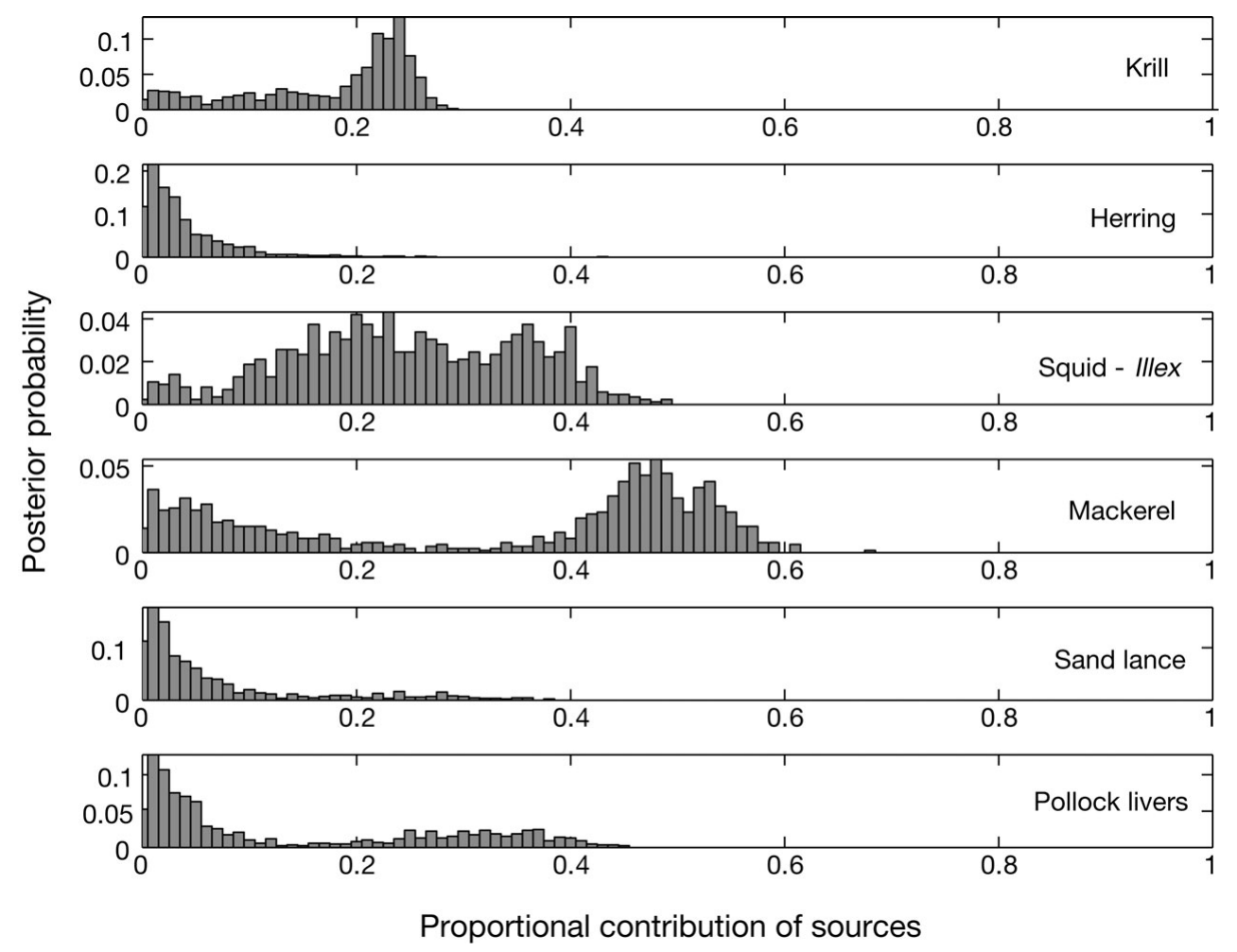

Fig. 5. Puffinus gravis. Model solutions using MixSIR mixing model to estimate contribution of different prey items in greater shearwater diets in 2008. Histograms show the posterior Bayesian model estimates for prey contributions. Bimodal distributions

(mackerel) and skewed distributions (sand lance, pollock, krill) illustrate the uncertainty in model solutions for this year

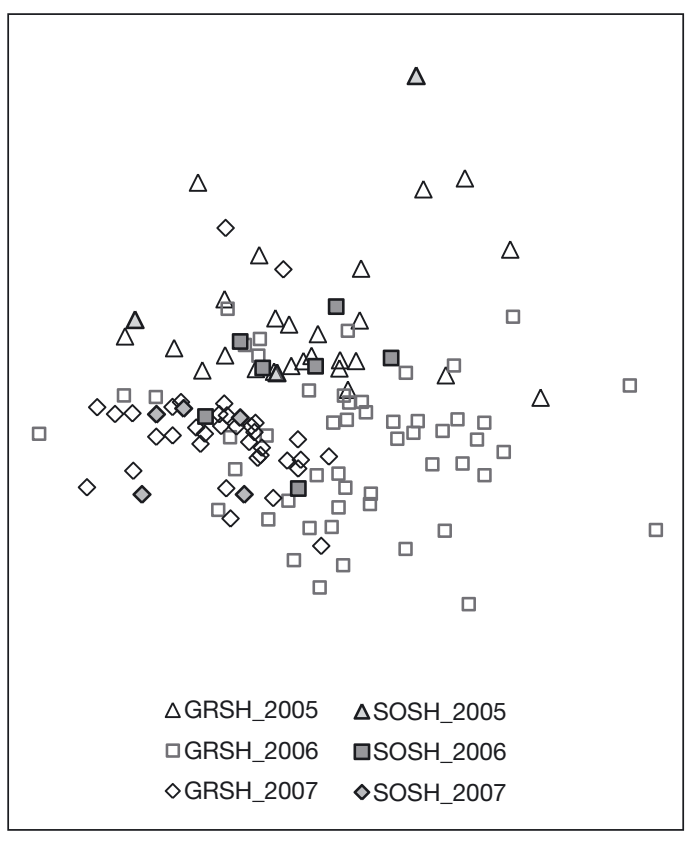

Fig. 6. Puffinus gravis and P. griseus. Multi-dimensional scaling (MDS) plot of greater (GRSH) and sooty shearwater (SOSH) fatty-acid signatures for 2005, 2006, and 2007, incorporating all fatty acids tively. These 2 DFs were able to distinguish the prey species and showed significant differences among all 3 (Wilks' lambda: $p<0.0001$; Fig. 7). Using crossvalidated classification, $98.9 \%$ of all prey cases were correctly classified. When the DF values for the shearwaters were superimposed on those of the 3 prey items, there appeared to be some overlap between birds and prey, at least for krill (Fig. 7).

Based on the DFs created from the subset of 38 FAs, the majority of greater shearwaters were classified as 'krill', while the sooty shearwaters were largely split between 'krill' and 'herring' (Table 4). In 2005, herring constituted the highest fraction of classified birds. For both greater and sooty shearwaters, a higher proportion of birds were classified as 'krill' in 2006 than in either of the other 2 years. In 2007, there was more of a spread between greater and sooty shearwater diets in terms of proportions of predicted prey classes (Table 4), although there was a trend of an increasing fraction of birds classified as 'squid' for both species in 2007 compared to the other 2 years.

The probability that birds were correctly classified as herring or krill by the DFS was $0.99 \pm 0.003$ for greater and $0.93 \pm 0.066$ for sooty shearwaters in the herring group, and $0.98 \pm 0.006$ for greater and $0.99 \pm 0.01$ for 


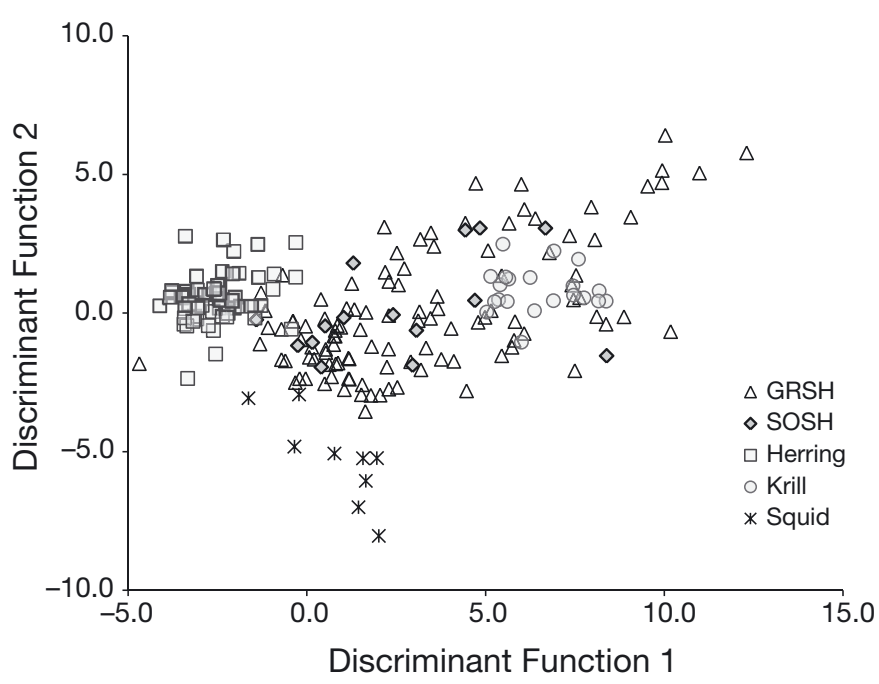

Fig. 7. Puffinus gravis and P. griseus. Discriminant function plot of DF1 vs. DF2 values for greater (GRSH) and sooty shearwater (SOSH) and potential prey items; DFs were constructed based on principal components generated from a subset of 38 fatty acids from prey only. Bird values were calculated from the DFs and superimposed on the prey data

Table 4. Puffinus gravis and P. griseus. Classification of potential prey items for greater and sooty shearwaters, based on discriminant function analysis of 38 selected fatty acids

\begin{tabular}{|lccc|}
\hline $\begin{array}{l}\text { Species } \\
\text { Year }\end{array}$ & $\begin{array}{c}\text { Krill } \\
\mathrm{n}(\%)\end{array}$ & $\begin{array}{c}\text { Herring } \\
\mathrm{n}(\%)\end{array}$ & $\begin{array}{c}\text { Squid (Illex) } \\
\mathrm{n}(\%)\end{array}$ \\
\hline $\begin{array}{l}\text { Greater shearwater } \\
2005\end{array}$ & $9(35)$ & $15(58)$ & $2(7)$ \\
2006 & $46(88)$ & $4(8)$ & $2(4)$ \\
2007 & $1(3)$ & $12(35)$ & $21(62)$ \\
Years pooled & $\mathbf{5 6 ( 5 0 )}$ & $\mathbf{3 1}(\mathbf{2 8 )}$ & $\mathbf{2 5} \mathbf{( 2 2 )}$ \\
Sooty shearwater & & & \\
2005 & $1(33)$ & $2(67)$ & 0 \\
2006 & $5(71)$ & $2(29)$ & 0 \\
2007 & $1(20)$ & $3(60)$ & $1(20)$ \\
Years pooled & $\mathbf{7 ( 4 7 )}$ & $\mathbf{7 ( 4 7 )}$ & $\mathbf{1}(\mathbf{6})$ \\
\hline
\end{tabular}

sooty shearwaters in the krill group. For both species, the probabilities for being assigned to the 'squid' group were lower $(0.81 \pm 0.04$ for greater and 0.72 for sooty shearwaters). However, in all cases, the model assigned each bird to a prey species with $>50 \%$ probability, with most confidence levels exceeding $80 \%$.

\section{DISCUSSION}

\section{Shearwater diets}

The present study represents the first investigation of the feeding habits of shearwaters in their northern hemisphere feeding grounds using biological markers that integrate dietary information over time. Until now, 'snapshot' analyses of proventriculus and gizzard contents have been the only sources of diet information for shearwater feeding habits in the western North Atlantic. Rees (1961) examined stomach contents of greater shearwaters caught from fishing vessels on the Grand Banks. Although stomachs contained capelin Mallotus villosus, euphausiids Thysanoessa inermis, and fish livers, Rees (1961) suggested that squid Illex illecebrosus, making up $47 \%$ by volume, was the only live prey item caught by shearwaters, the remainder likely originating from fishing-vessel discards, including discards of cod Gadus morhua stomachs. Stomachcontent analyses elsewhere have also identified cephalopods as the primary prey items of greater and sooty shearwater stomachs (Moser \& Lee 1992, Petry et al. 2008), but this is likely, in part, due to the long retention time of squid beaks in stomachs. Studies of stomach contents in the Bay of Fundy from 1974 to 1975 revealed mixed diets of squid (Illex), euphausiids, and fish, including herring, mackerel, and sand lance, for both greater and sooty shearwaters (Brown et al. 1981). Brown et al. (1981) concluded that greater shearwaters preyed more on squid and tough-bodied fish (mackerel), whereas sooty shearwaters fed more on euphausiids and soft-bodied fish (herring).

Our data from regurgitates, SI, and FA analyses show mixed diets for both species, and suggest that on feeding grounds in the Bay of Fundy, these species are not only sympatric in their distribution but also have similar diets. There were no differences in FA signatures between the 2 shearwater species and only minor differences in SI signatures. Interestingly, however, the subtle differences in $\delta^{15} \mathrm{~N}$ and $\delta^{13} \mathrm{C}$ were consistent in magnitude and direction during each year of the study. $\delta^{15} \mathrm{~N}$ values for greater shearwaters were consistently higher than those of sooty shearwaters in all years, showing a mean difference of $0.37,0.15,0.26$, 0.42 , and $0.64 \%$ in 2005 through 2009 respectively. Assuming a step-wise increase of $2.75 \%$ per trophic level for piscivorous birds (see 'Materials and methods'), this represents a small to moderate (0.05 to 0.23 ) difference in trophic level between species. Moreover, $\delta^{13} \mathrm{C}$ values were consistently higher in sooty shearwaters, also suggesting subtle differences in diet source. Alternatively, these species may possess some inherent differences in physiology resulting in differential isotopic discrimination between predator and prey stable isotope signatures - isotopic discrimination factors do vary among species (Cherel et al. 2005b) but they are unknown for any Puffinus species, thus, we can only rely on published data from other piscivorous seabirds. In other sympatric shearwaters, diet partitioning based on habitat use is thought to be an impor- 
tant mechanism facilitating coexistence among closely related species (Navarro et al. 2009). Further examination of diet through SI in feathers may reveal greater partitioning between greater and sooty shearwaters during other periods of the year.

Isotopic mixing models estimated krill, herring, and Illex as the primary food sources of both shearwater species; thus, species-specific differences in isotopic signatures (Fig. 3) are likely a result of additional food sources such as mackerel and sand lance. This is broadly consistent with findings by Brown et al. (1981), who suggested that squid and mackerel are consumed more frequently by greater shearwaters. Differences in prey selection between these species may arise from differences in bill structure and underwater swimming ability (Brown et al. 1981). Sooty shearwaters have been recorded to dive to depths exceeding $60 \mathrm{~m}$ (Shaffer et al. 2006); greater shearwater can dive to $\sim 19 \mathrm{~m}$ (Ronconi et al. 2010b), but they are typically thought to seize prey from the surface and from shallow $(<10 \mathrm{~m})$ dives (Brown et al. 1978). Despite this potential for niche partitioning, it seems that greater and sooty shearwater diets in the Northwest Atlantic broadly overlap, yet the 2 species are potentially consuming slightly different proportions of the same suite of prey. As with other shearwaters (R. Käkelä et al. 2010), we found less reliance on fisheries discards (e.g. pollock livers), presumably due to the recent low intensity of ground fish harvest in the Bay of Fundy, and a diet dominated primarily by naturally occurring pelagic prey.

Although we observed limited overall differences in diets between species, the SI analysis showed considerable within-species variability in diet. $\delta^{15} \mathrm{~N}$ values in shearwater blood ranged from 10.81 to $14.68 \%$ o in greater shearwaters but only 12.97 to $13.72 \%$ for sooty shearwaters. Assuming a 2.75\% increase per trophic level, this suggests a more varied diet among individual greater shearwaters (1.41 trophic-level spread) than for sooty shearwaters (0.38 trophic level). This range in $\delta^{15} \mathrm{~N}$ values was correlated, in some years, with body condition, suggesting that heavier birds were feeding at higher trophic levels. In times of nutritional stress, such as periods of prolonged starvation, SI signatures may be affected since nutritional stress can lead to $\delta^{15} \mathrm{~N}$ enrichment (Cherel et al. 2005a). Instead we saw the opposite trend with shearwaters, in which the underweight individuals (negative BCI) had the lowest $\delta^{15} \mathrm{~N}$ levels. This suggests that correlations between diet $\left(\delta^{15} \mathrm{~N}\right)$ and body condition were likely a consequence of nutritional quality (trophic level of prey) rather than physiological processes affecting $\delta^{15} \mathrm{~N}$ levels. With respect to reproductive performance in other seabirds, higher trophic-level prey may be considerably more valuable than lower trophic- level prey (Ainley et al. 2003, Norris et al. 2007). However, the influence of feeding trophic level on replenishment of body reserves during migratory staging is not known.

\section{Inter-annual variation in diets}

Many seabirds show within-season (e.g. Navarro et al. 2007) and inter-annual variability in diets (e.g. Tierney et al. 2008, Williams et al. 2008), although there is little documentation of such shifts outside of the breeding season. Year was the most important variable explaining variability in SI signatures, and analysis of FA revealed significant differences among years in plasma FA signatures. Changes in dietary FA and SI can arise from 2 sources: (1) through diet shifts, or (2) via alterations in the lipid and SI composition of the prey. The second source can result from a variety of factors, including changes in lower trophic levels, reduction in the quality of food available to prey, or abiotic influences on physiology, such as fluctuations in water temperature (Frazer et al. 1997, Dalsgaard et al. 2003). We suspect that the variation we observed in shearwater lipids and isotopes reflects both influences.

In many marine ecosystems, prey organisms exhibit considerable temporal variability in FA and SI signatures (Henderson et al. 1998, Dalsgaard et al. 2003, Jensen et al. 2007), clouding interpretation of these data in predators. Herring in the Bay of Fundy are known to exhibit significant annual variation in both lipid content and FA composition (Lane et al. in press). Whether krill and squid exhibit similar patterns has not yet been tested; our sample sizes were too small to permit this comparison. However, all prey species in the present study exhibited inter-annual variability in SI signatures, which could clearly have contributed to inter-annual differences in shearwater signatures; e.g. decreases in $\delta^{13} \mathrm{C}$ of several prey species in 2007 likely contributed to lower $\delta^{13} \mathrm{C}$ values in shearwater blood during that year. This argues for synoptic sampling of prey and predators in each year for studies investigating diets of animals using biochemical markers such as FA and SI.

Taking into account inter-annual changes in the prey base, our data also point to shifts in predator diets from year to year. SI mixing models estimated herring and krill to be primary prey items in early years, with a shift towards increased squid and decreased herring from 2007 onwards. Inter-annual comparison of sooty shearwater diets should be regarded with caution due to small sample sizes in some years, yet the patterns were similar to those observed for greater shearwaters and, therefore, the trend appears to be consistent for this foraging guild. FA data show general agreement with SI results, with the prediction model suggesting that 
overall, shearwaters consumed more herring and krill than they did squid, except in 2007. Thus, we hypothesize that shearwater diets have undergone a fundamental shift in the Bay of Fundy in recent years, with the break occurring between 2006 and 2007. The cause of this shift is unknown but transitions in seabird diets in other regions have been linked to changes in food webs driven by changes in oceanographic conditions (Montevecchi 2007). This may include very broad-scale oceanographic regime changes that alter the prey base (Hare \& Mantua 2000, Gaston et al. 2009). Such shifts associated with warm waters in the Northwest Atlantic have been linked directly with the increase of warm-water prey, such as mackerel and squid, in the diets of seabirds (Montevecchi \& Myers 1995). It is plausible that similar oceanographic alterations may have contributed to dietary changes observed in the present study. As generalist predators, taking advantage of prey items found in reliably high abundance at 2 trophic levels in the Bay of Fundy, shearwaters may be more reliable as indicator species for ecosystem change than other upper trophic-level consumers in the bay, which are typically specialized for either krill or herring (e.g. whales and some seabirds).

\section{Fatty acid data and analysis considerations}

The integration of SI and FA analyses is recognized as a powerful indirect method for studying the diet of wild animals, but this approach is not without its challenges and limits. Though most of the food sources known to be consumed by shearwaters in the Bay of Fundy (Brown et al. 1981) were included in the SI mixing, similar prey data were not available for the FA modeling. This may have contributed to discrepancies between FA and SI diet estimates (Tables $3 \& 4$ ), particularly when FA models estimated high krill consumption in 2006. In addition, a complete prey library should include a greater number of prey samples and species, sampled synoptically with the birds to detect the temporal variability in FA and SI signatures in prey. Thus we intend our interpretation of the data presented here to serve only as a very broad picture of shearwater diets. SI signatures change in predictable ways from predator to prey and our understanding of these processes is quite good for avian species (Hobson \& Clark 1992). Yet, our appreciation of the avian lipid transport system lags behind the level of knowledge of the corresponding processes in mammals (Stevens 1996). The use of blood lipids for dietary analyses is more complicated, especially for birds (see 'Introduction'), as metabolic processes will mask dietary signals (Stevens 1996, Klasing 1998, Williams \& Buck 2010).
Tierney et al. (2008) used the entire FA composition of whole blood to investigate variation in the diets of Adélie penguins Pygoscelis adeliae at their breeding colonies. They noted that levels of some FA (notably 14:0, 16:1n-7, 18:0, 18:4n-3, 20:4n-6, and 22:6n-3; almost all of which we excluded from our FA subset) 'bore little resemblance' to proportions found in known prey items, lending further support to the use of a reduced subset of FA for dietary reconstructions.

R. Käkelä et al. (2005) were able to distinguish between demersal and pelagic species in diets of herring gulls Larus argentatus using 2 different plasma FA ratios: a saturated/monounsaturated ratio (SAT; (iso17:0+ante17:0+17:1)/(14:0+20:1n-9+22:1n-11)) and a polyunsaturated ratio (PUFA; $(20: 4 n-6) /(18: 3 n-3$ $+18: 4 n-3+20: 5 n-3)$ ). Plotting values of these ratios against each other for our shearwaters and potential prey (Fig. 8) demonstrates distinct separation between birds and dietary items with the PUFA ratio, but some potential overlap between the birds with herring and squid for the SAT ratio. R. Käkelä et al.'s (2009) later study, aimed at linking plasma FA with diet in captive seabirds, identified several minor FAs (14:0, iso17:0, 18:1n-7, 18:3n-3, 18:4n-3, 20:1n-9, 22:1n-11, and 22:4n$6)$ that showed good correlation between plasma and diet, and suggested that these be used to monitor the diets of seabirds. We followed this approach with our data set and found no obvious clustering of birds with prey, and poorer resolution among prey items than through the use of our 38 FA subset (data not shown). Thus it appears that the selection of FAs to include in dietary prediction models may be species- and system-

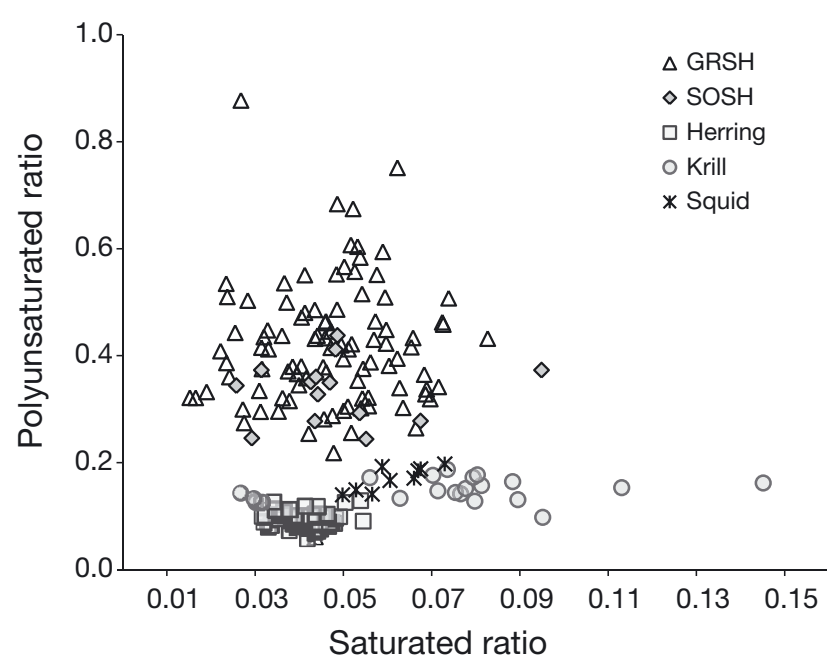

Fig. 8. Puffinus gravis and P. griseus. Plot of 2 fatty-acid ratios (saturated ratio: (iso17:0+ante17:0+17:1)/(14:0+20:1n-9+22:1 $\mathrm{n}-11)$ vs. polyunsaturated fatty acid ratio: $(20: 4 \mathrm{n}-6) /(18: 3 \mathrm{n}-3$ $+18: 4 \mathrm{n}-3+20: 5 \mathrm{n}-3)$ ) for greater (GRSH) and sooty shearwater (SOSH) and 3 potential prey items (krill, herring, and squid) 
specific when inferring diet using avian blood. Our data set is the first to sample the blood of 2 species of sympatric shearwaters over multiple years, and we feel that our understanding of the limitations of using blood FAs for diet inference, combined with our novel approach, has yielded some useful preliminary inferences about the diets of these birds. As confirmation, the results obtained from SI were in general agreement with inter-annual variability detected by FA. housie University) for advice on fatty acid data analysis. Funding was provided by the New Brunswick Wildlife Trust Fund, the James L. Baillie Fund for Bird Research and Preservation, GMWSRS, and UNCW. R.A.R. was supported by the Natural Sciences and Engineering Research Council of Canada (NSERC-CGS \& PDF) and the Killam Trust, Dalhousie University. Research was carried out under UNCW Institutional Animal Care and Use Committee approved protocols 2005-003 and 2007-007, banding permit 10480-S, and capture permits SC2429, SC2483, SC2543, SC2599, and SC2655 issued by the Canadian Wildlife Service.

\section{CONCLUSIONS}

With sufficient sample sizes of predators and prey, SI and FA analyses can be used to examine the diets of wild animals at 3 scales (see Tierney et al. 2008): (1) evaluating spatial, temporal, and ontogenetic variation in predator diets through changes in signals from predator tissues; (2) making general inferences about prey type and trophic level; and (3) estimating the contribution of different potential prey items to the diets of predators in a quantified, rather than just qualified, manner. We were able to compare SI and FA data from shearwaters to provide the first comparative insights into the diets of these birds in their winter feeding grounds in the Northwest Atlantic on 2 of these levels. We detected changes in the diets of greater and sooty shearwaters over time, and determined that the diets of the 2 species largely overlap, showing subtle partitioning in foraging preferences during non-breeding periods despite the fact that these 2 species have very disparate behaviors and distributions at other times of the year. We were also able to make inferences about which prey items might form the bulk of their diets. Further work, including additional sampling of birds and prey, and a full understanding of lipid metabolism in these birds, will be necessary to permit a more quantitative assessment of diet. Nonetheless, we have shown here that it is possible to study the diets of freeranging seabirds outside of their breeding seasons and away from their colonies, and that relatively less invasive sampling procedures (i.e. blood rather than other tissues) can yield important information about foraging habits of pelagic birds.

Acknowledgments. Many thanks to L. Murison and the Grand Manan Whale and Seabird Research Station (GMWSRS) for support with this project. We also thank the research assistants of GMWSRS, especially H. Lane and Z. Swaim, for their help in the field, and K. McReynolds (University of North Carolina Wilmington [UNCW]) for help with lipid extractions. Many of the prey samples were provided by the fishermen of Grand Manan Island. Thanks to T. Diamond (University of New Brunswick) for helping at the onset of this study, B. Hawkings (University of Victoria) and J. Dahn (Dalhousie University) for use of equipment, and S. Budge (Dal-

\section{LITERATURE CITED}

Abraham CL, Sydeman WJ (2004) Ocean climate, euphausiids and auklet nesting: inter-annual trends and variation in phenology, diet and growth of a planktivorous seabird, Ptychoramphus aleuticus. Mar Ecol Prog Ser 274:235-250

Ackman RG (1991) Application of gas-liquid chromatography to lipid separation and analysis: qualitative and quantitative analysis. In: Perkins EG (ed) Analysis of fats, oils and lipoproteins. American Oil Chemists Society, Chicago, IL, p 271-300

Ainley DG, Ballard G, Barton KJ, Karl BJ, Rau GH, Ribic CA, Wilson PR (2003) Spatial and temporal variation of diet within a presumed metapopulation of Adelie penguins. Condor 105:95-106

> Brooke M de L (2004) The food consumption of the world's seabirds. Proc R Soc Lond B 271(Suppl 4):S246-S248

Brown RGB (1986) Atlas of Canadian seabirds. Canadian Wildlife Service, Ottawa, ON

Brown RGB, Bourne WRP, Wahl TR (1978) Diving by shearwaters. Condor 80:123-125

Brown RGB, Barker SP, Gaskin DE, Sandeman R (1981) The foods of the great and sooty shearwaters Puffinus gravis and P. griseus in Eastern Canadian waters. Ibis 123:19-30

Budge SM, Iverson SJ, Koopman HN (2006) Studying trophic ecology in marine ecosystems using fatty acids: a primer on analysis and interpretation. Mar Mamm Sci 22:759-801

> Budge SM, Springer AM, Iverson SJ, Sheffield G (2007) Fatty acid biomarkers reveal niche separation in an Arctic benthic food web. Mar Ecol Prog Ser 336:305-309

Burnham KP, Anderson DR (2002) Model selection and multimodel inference: a practical information-theoretic approach. Springer-Verlag, New York, NY

Cairns DK (1987) Seabirds as indicators of marine food supplies. Biol Oceanogr 5:261-271

Cherel Y, Hobson KA, Bailleul FR, Groscolas R (2005a) Nutrition, physiology, and stable isotopes: new information from fasting and molting penguins. Ecology 86:2881-2888

Cherel Y, Hobson KA, Hassani S (2005b) Isotopic discrimination between food and blood and feathers of captive penguins: implications for dietary studies in the wild. Physiol Biochem Zool 78:106-115

> Cherel Y, Le Corre M, Jaquemet S, Menard F, Richard P, Weimerskirch $H$ (2008) Resource partitioning within a tropical seabird community: new information from stable isotopes. Mar Ecol Prog Ser 366:281-291

Clarke KR (1993) Nonparametric multivariate analyses of changes in community structure. Aust J Ecol 18:117-143

Clarke K, Gorley R (2006) PRIMER v6: user manual/tutorial. PRIMER-E, Plymouth

> Connan M, Mayzaud P, Boutoute M, Weimerskirch H, Cherel Y (2005) Lipid composition of stomach oil in a procellariiform seabird Puffinus tenuirostris: implications for food web studies. Mar Ecol Prog Ser 290:277-290 
Cooper MH, Iverson SJ, Heras H (2005) Dynamics of blood chylomicron fatty acids in a marine carnivore: implications for lipid metabolism and quantitative estimation of predator diets. J Comp Physiol B 175:133-145

Dahl TM, Falk-Petersen S, Gabrielsen GW, Sargent JR, Hop $\mathrm{H}$, Millar RM (2003) Lipids and stable isotopes in common eider, black-legged kittiwake and northern fulmar: a trophic study from an Arctic fjord. Mar Ecol Prog Ser 256: 257-269

Dalsgaard J, St John M, Kattner G, Muller-Navarra D, Hagen W (2003) Fatty acid trophic markers in the pelagic marine environment. Adv Mar Biol 46:225-340

Einoder LD (2009) A review of the use of seabirds as indicators in fisheries and ecosystem management. Fish Res 95: $6-13$

Folch J, Lees M, Sloane Stanley GH (1957) A simple method for the isolation and purification of total lipids from animal tissues. J Biol Chem 226:497-509

Frazer TK, Ross RM, Quetin LB, Montoya JP (1997) Turnover of carbon and nitrogen during growth of larval krill, Euphausia superba Dana: a stable isotope approach. J Exp Mar Biol Ecol 212:259-275

> Gannes LZ, del Rio CM, Koch P (1998) Natural abundance variations in stable isotopes and their potential uses in animal physiological ecology. Comp Biochem Physiol A 119: 725-737

Gaston AJ, Bertram DF, Boyne AW, Chardine JW and others (2009) Changes in Canadian seabird populations and ecology since 1970 in relation to changes in oceanography and food webs. Environ Rev 17:267-286

Green AJ (2001) Mass/length residuals: measures of body condition or generators of spurious results? Ecology 82: 1473-1483

Hare SR, Mantua NJ (2000) Empirical evidence for North Pacific regime shifts in 1977 and 1989. Prog Oceanogr 47: 103-145

> Henderson RJ, Hegseth EN, Park RT (1998) Seasonal variation in lipid and fatty acid composition of ice algae from the Barents Sea. Polar Biol 20:48-55

Hobson KA, Clark RG (1992) Assessing avian diets using stable isotopes $\mathrm{I}$ : turnover of ${ }^{13} \mathrm{C}$ in tissues. Condor 94 : 181-188

Hobson KA, Piatt JF, Pitocchelli J (1994) Using stable isotopes to determine seabird trophic relationships. J Anim Ecol 63: $786-798$

- Huettmann F, Diamond AW (2000) Seabird migration in the Canadian northwest Atlantic Ocean: moulting locations and movement patterns of immature birds. Can J Zool 78: 624-647

Huettmann F, Diamond AW, Dalzell B, MacIntosh K (2005) Winter distribution, ecology and movements of razorbills Alca torda and other auks in the outer Bay of Fundy, Atlantic Canada. Mar Ornithol 33:161-171

Iverson S (1988) Composition, intake, and gastric digestion of milk lipids in pinnipeds. PhD thesis, University of Maryland, College Park

> Iverson SJ, Field C, Bowen WD, Blanchard W (2004) Quantitative fatty acid signature analysis: a new method of estimating predator diets. Ecol Monogr 74:211-235

- Iverson SJ, Springer AM, Kitaysky AS (2007) Seabirds as indicators of food web structure and ecosystem variability: qualitative and quantitative diet analyses using fatty acids. Mar Ecol Prog Ser 352:235-244

> Jensen KN, Jacobsen C, Nielsen HH (2007) Fatty acid composition of herring (Clupea harengus L.): influence of time and place of catch on n-3 PUFA content. J Sci Food Agric 87:710-718
Johnston DW, Thorne LH, Read AJ (2005) Fin whales Balaenoptera physalus and minke whales Balaenoptera acutorostrata exploit a tidally driven island wake ecosystem in the Bay of Fundy. Mar Ecol Prog Ser 305:287-295

Käkelä A, Furness RW, Kelly A, Strandberg U, Waldron S, Käkelä R (2007) Fatty acid signatures and stable isotopes as dietary indicators in North Sea seabirds. Mar Ecol Prog Ser 342:291-301

Käkelä R, Käkelä A, Kahle S, Becker PH, Kelly A, Furness RW (2005) Fatty acid signatures in plasma of captive herring gulls as indicators of demersal or pelagic fish diet. Mar Ecol Prog Ser 293:191-200

Käkelä R, Furness RW, Kahle S, Becker PH, Käkelä A (2009) Fatty acid signatures in seabird plasma are a complex function of diet composition: a captive feeding trial with herring gulls. Funct Ecol 23:141-149

Käkelä R, Käkelä A, Martinez-Abrain A, Sarzo B and others (2010) Fatty acid signature analysis confirms foraging resources of a globally endangered Mediterranean seabird species: calibration test and application to the wild. Mar Ecol Prog Ser 398:245-258

Klasing KC (1998) Comparative avian nutrition. CAB International, New York, NY

Koopman HN, Iverson SJ, Gaskin DE (1996) Stratification and age-related differences in blubber fatty acids of the male harbour porpoise (Phocoena phocoena). J Comp Physiol B 165:628-639

Lane HA, Westgate AJ, Koopman HN (in press) Ontogenetic and temporal variability in the fat content and fatty acid composition of Atlantic herring (Clupea harengus) from the Bay of Fundy, Canada. Fish Bull

> Montevecchi WA (2007) Binary dietary responses of northern gannets Sula bassana indicate changing food web and oceanographic conditions. Mar Ecol Prog Ser 352:213-220

Montevecchi WA, Myers RA (1995) Prey harvests of seabirds reflect pelagic fish and squid abundance on multiple spatial and temporal scales. Mar Ecol Prog Ser 117:1-9

Moore JW, Semmens BX (2008) Incorporating uncertainty and prior information into stable isotope mixing models. Ecol Lett 11:470-480

> Moser ML, Lee DS (1992) A fourteen-year survey of plastic ingestion by western North-Atlantic seabirds. Colon Waterbirds 15:83-94

Navarro J, Gonzalez-Solis J, Viscor G (2007) Nutritional and feeding ecology in Cory's shearwater Calonectris diomedea during breeding. Mar Ecol Prog Ser 351:261-271

Navarro J, Forero MG, Gonzalez-Solis J, Igual JM, Becares J, Hobson KA (2009) Foraging segregation between two closely related shearwaters breeding in sympatry. Biol Lett 5:545-548

Norris DR, Arcese P, Preikshot D, Bertram DF, Kyser TK (2007) Diet reconstruction and historic population dynamics in a threatened seabird. J Appl Ecol 44:875-884

Petry MV, Fonseca VSD, Krueger-Garcia L, Piuco RD, Brummelhaus J (2008) Shearwater diet during migration along the coast of Rio Grande do Sul, Brazil. Mar Biol 154: 613-621

Phillips D, Gregg J (2003) Source partitioning using stable isotopes: coping with too many sources. Oecologia 136: 261-269

> Piatt JF, Sydeman WJ, Wiese F (2007) Introduction: a modern role for seabirds as indicators. Mar Ecol Prog Ser 352: 199-204

Rees EIS (1961) Notes on the food of the Greater Shearwater. Sea-Swallow 14:54-55

Rising JD, Somers KM (1989) The measurement of overall body size in birds. Auk 106:666-674 
Ronconi RA, Swaim ZT, Lane HA, Hunnewell RW, Westgate AJ, Koopman HN (2010a) Modified hoop-net techniques for capturing birds at sea and comparison with other capture methods. Mar Ornithol 38:23-29

Ronconi RA, Ryan PG, Ropert-Coudert Y (2010b) Diving of great shearwaters (Puffinus gravis) in cold and warm water regions of the South Atlantic Ocean. PLoS ONE 5:el15508

Semmens BX, Moore JW, Ward EJ (2009) Improving Bayesian isotope mixing models: a response to Jackson et al. (2009). Ecol Lett 12:E6-E8

Shaffer SA, Tremblay Y, Weimerskirch H, Scott D and others (2006) Migratory shearwaters integrate oceanic resources across the Pacific Ocean in an endless summer. Proc Natl Acad Sci USA 103:12799-12802

Shirihai H (2002) Complete guide to Antarctic wildlife. Princeton University Press, Princeton, NJ

Stevens L (1996) Avian biochemistry and molecular biology. Cambridge University Press, Cambridge

Suryan RM, Fischer KN (2010) Stable isotope analysis and satellite tracking reveal interspecific resource partitioning of nonbreeding albatrosses off Alaska. Can J Zool 88: 299-305

Tierney M, Nichols PD, Wheatley KE, Hindell MA (2008) Blood fatty acids indicate inter- and intra-annual variation in the diet of Adélie penguins: comparison with stomach content and stable isotope analysis. J Exp Mar Biol Ecol $367: 65-74$

Editorial responsibility: Yves Cherel, Villiers-en-Bois, France
Tucker S, Bowen WD, Iverson SJ (2008) Convergence of diet estimates derived from fatty acids and stable isotopes within individual grey seals. Mar Ecol Prog Ser 354: $267-276$

Wang SW, Iverson SJ, Springer AM, Hatch SA (2007) Fatty acid signatures of stomach oil and adipose tissue of northern fulmars (Fulmarus glacialis) in Alaska: implications for diet analysis of Procellariiform birds. J Comp Physiol B 177:893-903

Whitworth DL, Takekawa JY, Carter HR, McIver WR (1997) A night-lighting technique for at-sea capture of Xantus' Murrelets. Colon Waterbirds 20:525-531

Williams CT, Buck CL (2010) Using fatty acids as dietary tracers in seabird trophic ecology: theory, application and limitations. J Ornithol 151:531-543

Williams CT, Buck CL, Sears J, Kitaysky AS (2007a) Effects of nutritional restriction on nitrogen and carbon stable isotopes in growing seabirds. Oecologia 153:11-18

Williams CT, Kildaw SD, Buck CL (2007b) Sex-specific differences in body condition indices and seasonal mass loss in Tufted Puffins. J Field Ornithol 78:369-378

> Williams CT, Iverson SJ, Buck CL (2008) Stable isotopes and fatty acid signatures reveal age- and stage-dependent foraging niches in tufted puffins. Mar Ecol Prog Ser 363: 287-298

Zar JH (1996) Biostatistical analysis, 3rd edn. Prentice-Hall, Upper Saddle River, NJ

Submitted: June 9, 2010; Accepted: October 1, 2010 Proofs received from author(s): November 27, 2010 